\title{
Determinants of growth retardation in Southern Brazil
}

\author{
Determinantes do retardo \\ no crescimento no Sul do Brasil
}

\author{
1 Programa de Pós-graduação \\ em Saúde Coletiva, \\ Universidade Luterana \\ do Brasil, Canoas, Brazil. \\ 2 Programa de Pós-graduação \\ em Ciências da Saúde, \\ Universidade do Vale \\ do Rio dos Sinos, \\ São Leopoldo, Brazil. \\ 3 Universidade Estadual \\ do Rio Grande do Sul, \\ Porto Alegre, Brazil. \\ 4 Faculdade de Medicina \\ Universidade Federal \\ do Rio Grande do Sul. \\ Porto Alegre, Brazil. \\ Correspondence \\ D. Aerts \\ Programa de Pós-graduação \\ em Saúde Coletiva, \\ Universidade Luterana \\ do Brasil. \\ Av. Ganzo 238, \\ Porto Alegre, RS \\ 90150-070, Brasil. \\ daerts@via-rs.net
}

\section{Abstract}

A cross-sectional population-based study of determinants of growth retardation in under-five children $(3,389)$ in the city of Porto Alegre, Rio Grande do Sul, Brazil estimated odds ratios (OR) for stunting, defined as height-for-age $<-2$ $z$-scores of the NCHS standards. Hierarchical modeling based on a framework of the process of stunting was used. Stunting prevalence was $6.8 \%$; the main determinants were per capita family income $<0.8$ times the minimum wage (OR: 3.95; 95\%CI: 2.10-7.42), maternal illiteracy (OR: 17.17; 95\%CI: 4.43-66.54), living in a wooden or mixed-construction house (OR: 2.33; 95\%CI: 1.35-4.01), inadequate housing (OR: 2.75; 95\%CI: 1.70-4.43), maternal age at the child's birth < 20 years (OR: 1.73; 95\%CI: 1.112.70), being an adopted child (OR: 3.28; 95\%CI: 1.52-7.07), third-born child or greater (OR: 2.04; 95\%CI: 1.15-3.62), birth interval < 24 months since previous child (OR: 1.69; 95\%CI: 1.132.53), subsequent sibling (OR: 1.91; 95\%CI: 1.163.13), multiple birth (OR: 2.40; 95\%CI: 1.045.50), low birth weight (OR: 3.79; 95\%CI: 2.386.02), and hospitalization in the first year of life (OR: 1,65; 95\%CI: 1.01-2.68). The findings can be used by primary healthcare services to design specific interventions to prevent stunting.

Growth Retardation; Malnutrition; Social Conditions
Denise Aerts 1

Maria de Lourdes Drachler 2,3

Elsa Regina Justo Giugliani 4

\section{Introduction}

Growth retardation is a major concern in developing countries, despite a decline in the past decades. In 2000, the estimated prevalence of stunting in children younger than five years was $34.4 \%$ in Asia, $35.2 \%$ in Africa, and $12.6 \%$ in Latin America and the Caribbean. Overall prevalence for developing countries was $32.5 \% 1$.

In Brazil, data from the last national census, carried out in 1996, indicate a reduction in stunting in the past decades; currently, the prevalence of stunting is $10.5 \%$ among children younger than five years 2 . While the peak height velocity for the Brazilian population coincides with $\mathrm{Na}$ tional Center of Health Statistics (NCHS) standards, after two years of age the growth of children is $5.0 \%$ slower than that reported by the NCHS 3 . Growth retardation has consequences throughout the lifespan, such as an increase in the risk of morbidity, mortality, developmental disability, and decrease in adult height, work capacity, and reproductive problems 1 .

Studies suggest that stunting has multiple and interrelated determinants that can be understood as organized in a hierarchical structure 4,5 . The most important proximal determinants are inadequate dietary intake and illness, usually infectious diseases that are affected by family access to food, water, sanitation, and adequate health services, and the quality of maternal and child-care practices. These living con- 
ditions of the child are influenced by structural factors at the societal level, particularly political, cultural, religious, economic, and social systems $4,5,6,7,8$.

This study investigates the effect of socioeconomic, immediate environmental, and individual determinants of growth retardation in children younger than five years in a large population-based survey in Porto Alegre, Rio Grande do Sul, Southern Brazil.

\section{Methods}

The study was carried out in the city of Porto Alegre, capital of the State of Rio Grande do Sul. The data analyzed herein were collected in 1990 as part of a cross-sectional study to investigate the nutritional status of 0 to 5 year-old children 9 . These are the most recent population data concerning the health conditions of the children in this area.

The size of the sample was calculated based on the estimated population of 107,902 children within the 0 to 5 year age range in 1990 , and on the estimated prevalence of anthropometrical deficits (10.0 to $30.0 \%$; maximal error $\pm 2 \%$ ) in this population. The calculation resulted in a sample of 3,379 for a $99 \%$ confidence level. This sample size had an $85.0 \%$ power to detect an odds ratio $\geq 2.0$ for the risk factors under study, considering a minimum prevalence of $10.0 \%$.

The sampling process was carried out in three stages. The first stage was the systematic sampling of 273 out of the 1,648 census tracts as defined by the Brazilian Institute of Geography and Statistics, or National Census Bureau (IBGE). The second stage was the systematic sampling of households, taking into consideration the proportion of children younger than five years living in each of the 273 tracts in relation to the total number of children in these areas. The third stage was a random sampling of one child per home.

A total of 3,475 children were selected, of whom $13(0.4 \%)$ were not enrolled because the family was not at the home after three visits. Seventy-three children (2.2\%) were not included due to refusal of the family to participate in the study. From the 3,389 children enrolled, a total of 34 children (1.0\%) were excluded: 8 for presenting diseases which affect growth (pituitary dwarfism, Down's syndrome, or severe cerebral palsy); 11 because the mother did not allow measuring the child's height or there were measurement errors in this variable; 15 children who did not have a biological, step, or adoptive mother were also excluded because their numbers were too small to allow analysis of the effect of absence of a social mother on growth.

Data were collected during a visit to the home through an interview, preferably with the mother, who answered a questionnaire after verbal consent. The study presented minimal risk for participants and was approved by the Ethics Committee at the Porto Alegre Municipal Health Department. The questionnaire encompassed three groups of variables (Figure 1): (a) societal processes were indicated by the socioeconomic variables (maternal and paternal schooling and absence of a father from the household and paid work, occupational status of the head of the household and per capita family income). A category "absence of social father" was created in the variable "paternal schooling" for children who did not live with a biological, adoptive, or step father; this prevented excluding a large number of children from the study and also allowed examining the effect of absence of father on child growth. At the time of the study, the money required for feeding one person in Porto Alegre was 0.83 times the prevailing minimum wage per month (one minimum wage $=\mathrm{U} \$ 65.00$ ); (b) the immediate environment of the child included housing (material and conditions) and family variables (type of parents, single parent, household size, main caretaker, mother's age at the child's birth, birth order, multiple birth, birth interval); and (c) individual variables which included age, gender, health conditions at birth (birth weight and gestational age) and hospitalization during the first and second years of life.

Children's height and length were measured following World Health Organization (WHO) guidelines, and stunting was defined as heightfor-age lower than -2z-score of the NCHS standards 10 .

Non-conditional logistic regression was used to estimate the odds ratio for stunting. The choice of possible confounders for each variable was based on the theoretical framework presented in Figure 1. This model emphasizes the importance of the societal level, with hierarchically inferior variables being gradually introduced in the regression models. In the first step of the logistic regression, the effect of socioeconomic variables was analyzed without adjustment for the variables belonging to low- 


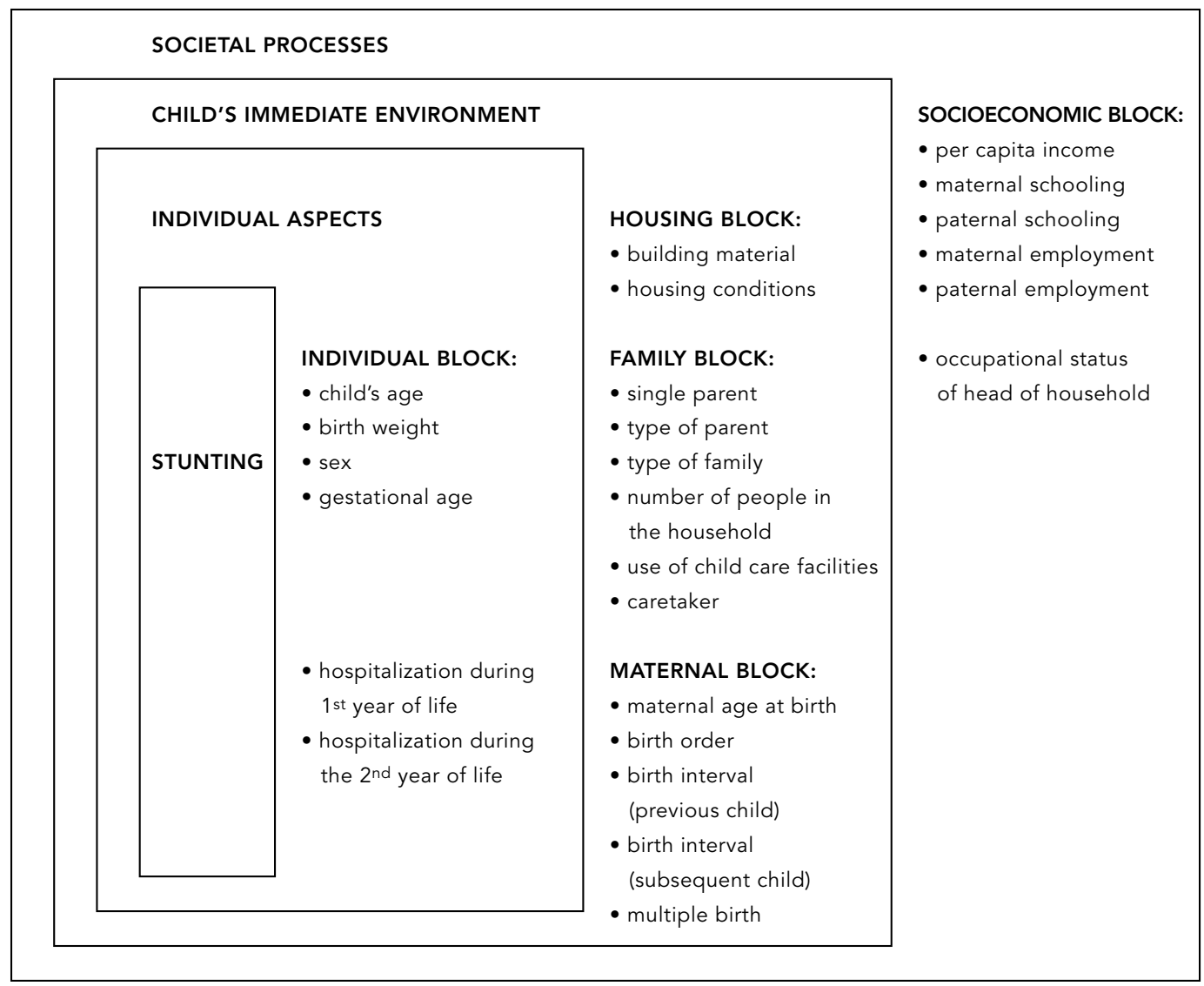

er levels. All the variables presenting an association with stunting $(\mathrm{p}<0.10)$ were kept in subsequent stages to be considered as potential confounders. The second step included variables of the child's immediate environment, controlled for the socioeconomic variables selected in step 1 . The variables of the immediate environment that were not shown to be associated with stunting ( $\mathrm{p} \geq 0.10$ ) were not included in the next step. In the third step, individual variables were included and controlled for hierarchically higher variables. The individual variables without statistical association with stunting were removed from the final model. Sex and age were included in step 3 as proximal determinants of growth retardation because they are not determined by societal and environmental variables. The adjusted odds ratio in the tables refer to the step in which the variable was included in the model. This analytical framework enabled us to assess whether the effect of each variable on growth was direct or mediated by other factors 11 . The final model includes only variables associated with stunting and their respective odds ratios as observed at the step when they were first entered into the model 11,12. A p-value $<0.05$ was considered significant.

\section{Results}

Prevalence of stunting was $6.8 \%$ and decreased with per capita income and maternal schooling ( $\chi^{2}$ for linear trend; $p<0.000$ ). These two variables were significantly associated with stunting in the first step of logistic regression (Table 1).

In the second step, housing variables presented a strong association with stunting, even after controlling for other variables on the same hierarchical level and for socioeconomic variables. Among six family variables, only type of parent (biological, step, or other) was associ- 
Association of the socioeconomic variables with stunting. Porto Alegre, Rio Grande do Sul, Brazil.

\begin{tabular}{|c|c|c|c|c|c|c|}
\hline \multirow[t]{2}{*}{ Variables } & \multicolumn{6}{|c|}{ Stunting } \\
\hline & $\mathrm{n}$ & $\mathrm{n}$ & $\%$ & $\begin{array}{l}\text { Adjusted } \\
\text { odds ratio* }\end{array}$ & $95 \% \mathrm{Cl}$ & p-value \\
\hline \multicolumn{7}{|l|}{ Mother has paid work } \\
\hline No & 1,532 & 98 & 6.4 & 0.76 & $0.54-1.07$ & 0.1134 \\
\hline Yes & 1,823 & 117 & 6.4 & 1.00 & - & - \\
\hline \multicolumn{7}{|l|}{ Father has paid work } \\
\hline No & 28 & 6 & 21.4 & 1.87 & $0.57-6.14$ & 0.3045 \\
\hline Yes & 2,867 & 173 & 6.0 & 1.00 & - & - \\
\hline Does not have social father ${ }^{\star *}$ & 460 & 36 & 7.8 & - & - & - \\
\hline \multicolumn{7}{|l|}{$\begin{array}{l}\text { Income per capita } \\
\text { (times minimum wage) }{ }^{\star \star \star}\end{array}$} \\
\hline 0.00 to 0.83 & 285 & 57 & 20.0 & 3.95 & $2.10-7.42$ & 0.0000 \\
\hline 0.84 to 1.50 & 455 & 52 & 11.4 & 2.36 & $1.29-4.33$ & 0.0056 \\
\hline 1.51 to 3.00 & 748 & 59 & 7.9 & 1.81 & $1.02-3.21$ & 0.0432 \\
\hline 3.01 to 5.00 & 531 & 22 & 4.1 & 1.21 & $0.65-2.29$ & 0.5456 \\
\hline$\geq 5.01$ & 1,336 & 25 & 1.9 & 1.00 & - & - \\
\hline \multicolumn{7}{|l|}{ Maternal schooling (years) ${ }^{\star \star \star}$} \\
\hline No schooling & 173 & 40 & 23.1 & 17.17 & $4.43-66.54$ & 0.0000 \\
\hline $0-4$ & 617 & 74 & 12.0 & 8.71 & $2.33-32.58$ & 0.0013 \\
\hline $5-8$ & 1,180 & 74 & 6.3 & 6.47 & $1.78-23.54$ & 0.0046 \\
\hline $9-11$ & 767 & 24 & 3.1 & 4.99 & $1.40-17.80$ & 0.0133 \\
\hline$\geq 12$ & 618 & 3 & 0.5 & 1.00 & - & - \\
\hline \multicolumn{7}{|l|}{ Paternal schooling (years) } \\
\hline Does not have social father & 460 & 36 & 7.8 & 1.33 & $0.42-4.23$ & 0.6307 \\
\hline No schooling & 117 & 20 & 17.1 & 1.80 & $0.61-5.32$ & 0.2853 \\
\hline $0-4$ & 442 & 67 & 15.2 & 2.33 & $0.87-6.21$ & 0.0896 \\
\hline $5-8$ & 1,004 & 63 & 6.3 & 1.30 & $0.50-3.34$ & 0.5874 \\
\hline $9-11$ & 687 & 22 & 3.2 & 1.27 & $0.50-3.23$ & 0.6133 \\
\hline$\geq 12$ & 645 & 7 & 1.1 & 1.00 & - & - \\
\hline \multicolumn{7}{|l|}{$\begin{array}{l}\text { Occupational status of head } \\
\text { of household }\end{array}$} \\
\hline Unemployed & 123 & 9 & 7.3 & 0.91 & $0.29-2.85$ & 0.8782 \\
\hline Blue-collar worker & 2,095 & 181 & 8.6 & 1.13 & $0.67-1.90$ & 0.6554 \\
\hline Employer & 78 & 2 & 2.6 & 1.85 & $0.41-8.33$ & 0.4200 \\
\hline Intellectual/technician & 1,059 & 23 & 2.2 & 1.00 & - & - \\
\hline
\end{tabular}

* First step of regression: adjusted for all the other variables in the table. ** Only for child with a father.

*** Variables selected for next step of logistic regression.

ated with stunting; all five maternal variables were associated with stunting (Table 2). The prevalence of stunting increased with birth or$\operatorname{der}\left(\chi^{2}\right.$ for linear trend; $\left.p<0.000\right)$. In this step, per capita income lost statistical significance (not in table).

In the third stage, in addition to the variables selected in step 1 and 2, individual variables were entered in the model (Table 3). Low birth weight $(<2,500 \mathrm{~g})$ was associated with risk of height-for-age deficit. No significant associ- ation was observed between sex and growth retardation. However, since the significance level was below 0.10 , this variable was not excluded. Gestational age was excluded from the final model because it did not present an association within stunting. Children younger than 24 months were twice as likely to present heightfor-age deficit when compared to older children. The duration of hospital admissions during the first year of life was positively associated with risk of stunting ( $\chi^{2}$ for linear trend; 
Association of child's immediate environment variables with stunting. Porto Alegre, Rio Grande do Sul, Brazil.

\begin{tabular}{|c|c|c|c|c|c|c|}
\hline \multirow[t]{2}{*}{ Variables } & \multicolumn{6}{|c|}{ Stunting } \\
\hline & $\mathrm{n}$ & $\mathrm{n}$ & $\%$ & $\begin{array}{l}\text { Adjusted } \\
\text { odds ratio* }\end{array}$ & $95 \% \mathrm{Cl}$ & $p$-value \\
\hline \multicolumn{7}{|l|}{ Building material ${ }^{\star \star}$} \\
\hline Masonry & 2,216 & 57 & 2.6 & 1.00 & - & - \\
\hline Wood and masonry & 235 & 24 & 10.2 & 2.03 & $1.35-3.05$ & 0.0007 \\
\hline Wood and other materials & 904 & 134 & 14.8 & 2.33 & $1.35-4.01$ & 0.0024 \\
\hline \multicolumn{7}{|l|}{$\begin{array}{l}\text { Housing conditions }{ }^{\star *} \text { (water and } \\
\text { sewer system, electricity) }\end{array}$} \\
\hline Satisfactory (three conditions) & 2,356 & 62 & 2.6 & 1.00 & - & - \\
\hline Fair (two conditions) & 562 & 66 & 11.7 & 2.08 & $1.35-3.20$ & 0.0009 \\
\hline Unsatisfactory (one or none) & 437 & 87 & 19.9 & 2.75 & $1.70-4.43$ & 0.0000 \\
\hline \multicolumn{7}{|l|}{ Single parent } \\
\hline No & 2,895 & 179 & 6.2 & 1.00 & - & - \\
\hline Yes & 460 & 36 & 7.8 & 1.01 & $0.65-1.59$ & 0.9470 \\
\hline \multicolumn{7}{|l|}{ Type of parent ${ }^{\star \star}$} \\
\hline Biological & 3,233 & 203 & 6.3 & 1.00 & - & - \\
\hline Step & 62 & 11 & 17.7 & 3.28 & $1.52-7.07$ & 0.0025 \\
\hline Other & 60 & 1 & 1.7 & 0.00 & $0.00-57.01$ & 0.4284 \\
\hline \multicolumn{7}{|l|}{ Type of family } \\
\hline Nuclear & 2,814 & 180 & 6.4 & 1.00 & - & - \\
\hline Extended & 541 & 35 & 6.5 & 1.15 & $0.70-1.89$ & 0.5819 \\
\hline \multicolumn{7}{|l|}{ Use of child care facilities } \\
\hline No & 2,758 & 196 & 7.1 & 1.15 & $0.68-1.96$ & 0.5994 \\
\hline Yes & 597 & 19 & 3.2 & 1.00 & - & - \\
\hline \multicolumn{7}{|l|}{ Number of people in household } \\
\hline $0-4$ & 2,008 & 82 & 4.1 & 1.00 & - & - \\
\hline $5-6$ & 911 & 71 & 7.8 & 0.97 & $0.56-1.69$ & 0.9184 \\
\hline 7 or more & 374 & 62 & 16.6 & 1.00 & $0.63-1.58$ & 0.9958 \\
\hline \multicolumn{7}{|l|}{ Caretaker } \\
\hline Social mother & 2,916 & 184 & 6.3 & 1.00 & - & - \\
\hline Other & 439 & 31 & 7.1 & 1.12 & $0.72-1.73$ & 0.6145 \\
\hline \multicolumn{7}{|l|}{$\begin{array}{l}\text { Maternal age at child's } \\
\text { birth (years) }\end{array}$} \\
\hline 20 or more & 2,863 & 167 & 5.8 & 1.00 & - & - \\
\hline Less than 20 & 492 & 48 & 9.8 & 1.73 & $1.11-2.70$ & 0.0154 \\
\hline \multicolumn{7}{|l|}{ Birth order ${ }^{\star \star}$} \\
\hline 1 st & 1,421 & 53 & 3.7 & 1.00 & - & - \\
\hline $2^{\text {nd }}$ & 930 & 42 & 4.5 & 1.31 & $0.81-2.10$ & 0.2668 \\
\hline $3 r d$ & 500 & 42 & 8.4 & 2.04 & $1.15-3.62$ & 0.0141 \\
\hline 4 th or more & 504 & 78 & 15.5 & 2.34 & $1.28-4.28$ & 0.0055 \\
\hline \multicolumn{7}{|l|}{ Multiple births ${ }^{\star \star}$} \\
\hline No & 3,306 & 208 & 6.3 & 1.00 & - & - \\
\hline Yes & 46 & 6 & 13.0 & 2.40 & $1.04-5.50$ & 0.0395 \\
\hline
\end{tabular}

(continued) 


\begin{tabular}{|c|c|c|c|c|c|c|}
\hline \multirow[t]{2}{*}{ Variables } & \multicolumn{6}{|c|}{ Stunting } \\
\hline & $\mathrm{n}$ & $\mathrm{n}$ & $\%$ & $\begin{array}{l}\text { Adjusted } \\
\text { odds ratio* }\end{array}$ & $95 \% \mathrm{Cl}$ & $p$-value \\
\hline \multicolumn{7}{|c|}{ Birth interval (previous child)** } \\
\hline$=24$ months & 2,981 & 154 & 5.2 & 1.00 & - & - \\
\hline$<24$ months & 308 & 49 & 15.9 & 1.69 & $1.13-2.53$ & 0.0107 \\
\hline Adopt child & 62 & 11 & 17.7 & 3.28 & $1.52-7.07$ & 0.0025 \\
\hline \multicolumn{7}{|c|}{$\begin{array}{l}\text { Birth interval (subsequent } \\
\text { childbirth)** }\end{array}$} \\
\hline$=24$ months & 3,100 & 175 & 5.6 & 1.00 & - & - \\
\hline$<24$ months & 188 & 28 & 14.9 & 1.91 & $1.16-3.13$ & 0.0103 \\
\hline Adopt child & 62 & 11 & 17.7 & 3.28 & $1.52-7.07$ & 0.0025 \\
\hline
\end{tabular}

* Second step of regression: adjusted for all the other variables in the table, maternal schooling,

and per capita family income.

** Variables selected for next step of logistic regression.

$\mathrm{p}<0.000$ ), and this association was also shown to be highly significant in the multivariate model. There was no evidence of association between stunting and hospital admissions in the second year of life, and this variable was excluded from the model. In this step, multiple birth lost statistical significance (not in table).

\section{Discussion}

This study has shown several determinants of growth retardation. Among the societal variables, only income and maternal schooling were significantly associated with height deficit. Maternal schooling had the strongest effect on growth, with little variation in magnitude throughout all steps of logistic regression. Children of illiterate mothers were 17 times more likely to present growth deficit than the children of mothers with 11 years of schooling, which reflects the importance of educated mothers for the development of healthy children, as most investigators have observed 13,14,15,16,17. Since maternal work was not associated with stunting in the present study, it is likely that the importance of maternal schooling in child growth is more related to the child rearing practices than the mother's contribution to family income.

The effect of per capita income on growth deficits can be explained by its importance for the purchase of food and consumer goods that promote and protect the health of children. Several authors have observed a positive association between low income and malnutrition $14,16,17,18,19$. Height deficit has been specifically associated with income of three or fewer times the minimum wage; there appears to be no difference in terms of risk for different income ranges above this level. In the present study, children from families with lower incomes were four times more likely to present stunting than children in the group above five times the minimum wage.

The introduction of factors related to the child's immediate environment resulted in complete loss of the effect of income on growth retardation, which occurred after inclusion of housing materials and conditions. This suggests that part of the positive effect of income on child height was mediated by the quality of family housing, a proxy of resources invested on quality of life. As in another study 16, living in non-masonry housing without basic infrastructure increased the likelihood of stunting. A small part of the effect of housing conditions appears to be mediated by gestational age, birth weight, hospitalization, and demographic variables (individual variables in the third stage of the analysis). The weak mediation may be explained by the lack of variables measuring morbidity which do not require hospitalization, mainly infectious diseases 8 . Investigation of these variables, if carried out, would have introduced recall bias into the study.

Among the variables of the family environment, only type of parent was statistically significant after adjustment for confounding, with step parent being a risk factor for stunting. This may be partially explained by the worse health status of adopted children prior to adoption. Similarly to what was observed by Victora et al. 20 , type of family and number of family members were not associated with growth deficit in the present study. It is possible that the effect 
Association of individual variables with stunting. Porto Alegre, Rio Grande do Sul, Brazil.

\begin{tabular}{|c|c|c|c|c|c|c|}
\hline \multirow[t]{2}{*}{ Variables } & \multicolumn{6}{|c|}{ Stunting } \\
\hline & $n$ & $\mathrm{n}$ & $\%$ & $\begin{array}{l}\text { Adjusted } \\
\text { odds ratio* }\end{array}$ & $95 \% \mathrm{Cl}$ & p-value \\
\hline \multicolumn{7}{|l|}{ Birth weight (grams) ${ }^{\star \star}$} \\
\hline$=2,500$ & 3,092 & 166 & 5.4 & 1.00 & - & - \\
\hline$<2,500$ & 263 & 49 & 18.8 & 3.79 & $2.38-6.02$ & 0.0000 \\
\hline \multicolumn{7}{|l|}{ Gestational age (weeks) } \\
\hline$=37$ & 3,206 & 198 & 6.2 & 1.00 & - & - \\
\hline$<37$ & 149 & 17 & 11.9 & 0.78 & $0.39-1.55$ & 0.4756 \\
\hline \multicolumn{7}{|l|}{ Sex } \\
\hline Female & 1,666 & 93 & 5.7 & 1.00 & - & - \\
\hline Male & 1,689 & 122 & 7.3 & 1.36 & $0.99-1.86$ & 0.0541 \\
\hline \multicolumn{7}{|l|}{$\mathrm{Age}^{\star \star}$ (months) } \\
\hline $0-11$ & 698 & 50 & 7.2 & 2.02 & $1.19-3.42$ & 0.0087 \\
\hline $12-23$ & 758 & 62 & 8.2 & 2.25 & $1.36-3.71$ & 0.0015 \\
\hline $24-35$ & 658 & 29 & 4.4 & 1.00 & - & - \\
\hline $36-47$ & 651 & 35 & 5.4 & 1.27 & $0.73-2.22$ & 0.3894 \\
\hline $48-59$ & 590 & 39 & 6.6 & 1.40 & $0.81-2.42$ & 0.2254 \\
\hline \multicolumn{7}{|l|}{$\begin{array}{l}\text { Hospitalization during } \\
\text { first year of life (days)** }\end{array}$} \\
\hline Child was not hospitalized & 2,727 & 126 & 4.6 & 1.00 & - & - \\
\hline $1-7$ & 269 & 28 & 10.4 & 1.65 & $1.01-2.68$ & 0.0424 \\
\hline $8-30$ & 273 & 36 & 13.2 & 1.71 & $1.09-2.70$ & 0.0196 \\
\hline More than 30 & 86 & 25 & 29.1 & 2.48 & $1.37-4.50$ & 0.0028 \\
\hline \multicolumn{7}{|l|}{$\begin{array}{l}\text { Hospitalizations during } \\
\text { second year of life }\end{array}$} \\
\hline No & 3,228 & 194 & 6.0 & 1.00 & - & - \\
\hline Yes & 127 & 21 & 16.5 & 1.16 & $0.65-2.10$ & 0.6102 \\
\hline
\end{tabular}

* Third step of regression: adjusted for all the other variables in the table, maternal schooling, per capita family income, housing materials and conditions, type of parent, maternal age at the child's birth, birth order, multiple births, previous and subsequent birth interval.

$\star \star$ Variables selected.

of these variables is better demonstrated by per capita income, which expresses the relationship between income and the number of family members.

The children of mothers younger than 20 years were almost twice as likely to present stunting. A study that addressed this issue has reported that adolescent pregnancy is usually not planned 21. Furthermore, teenage pregnancy is more common in economically disadvantaged populations, and adolescent mothers tend to have little experience in child rearing and are likely to have few years of education 22 .

Similarly to other studies, birth order greater then second 23,24 and birth interval less then 24 months 24,25 and multiple birth were shown to be a risk for stunting in the present study. The effect of multiple birth and short birth interval on growth retardation may be due to the higher risk of low birth weight and inadequate maternal care, which are associated with an increase in the prevalence of health problems, compared to birth interval greater than 24 months or single child 26.

Birth weight was the individual variable with the strongest effect on height. Low birth weight increased the odds of stunting 3.8-fold. There was no evidence that gestational age had an effect on stunting after adjustment for confounding (step 3), perhaps due to the association between low birth weight and preterm birth. Other studies have also observed a significant association between low birth weight and stunting 14,27. Those investigators state that socioeconomic conditions have an effect on the growth of children with low birth weight. 
Hospital admissions during the first year of life increased the likelihood of growth retardation. Other studies have shown that these hospitalizations usually occur as a result of low birth weight, premature birth, respiratory infection, and diarrhea and have reported a positive association between infections and anthropometric deficits 8,28,29,30.

The proportion of stunting was higher for children younger then two years as observed in different countries where stunting is prevalent $1,6,15$. Age effects should be interpreted with caution because this is a cross-sectional study. Furthermore, this age effect may be partially explained by the disjunction in the NCHS growth curves due to differences in the reference population for children younger than 24 months (The FELS longitudinal study - FELS study) and for those between 2 and 18 years old (NCHS study) 31 . This age effect could be decreased by the use of the Centers for Disease Control and Prevention smoothed growth curves 32. However, the NCHS curves are recommended by the WHO as the international reference until the new WHO international curves become available 33 .

The data were collected in 1990, but the circumstances addressed in this study appear to have changed little in Porto Alegre. In the pre-

\section{Resumo}

Estudo transversal de base populacional sobre os determinantes do retardo no crescimento de crianças com menos de cinco anos (3.389), em Porto Alegre, Rio Grande do Sul, Brasil, definido como índice alturalidade <-2 desvios-padrão do National Center for Health Statistics. Foi utilizado um modelo multivariado hierarquizado para ajustar o confundimento. A prevalência de retardo no crescimento foi de 6,8\%. As crianças com maior prevalência tinham as seguintes características: renda per capita $<0,8$ salário mínimo (RC: 3,95; IC95\%: 2,10-7,42), mães sem escolaridade (RC: 17,17; IC95\%: 4,43-66,54), moravam em casas de madeira ou mistas (RC: 2,33; IC95\%: 1,35-4,01), inadequadas condições de moradia (RC: 2,75; IC95\%: 1,70-4,43), idade materna ao nascimento $<20$ anos (RC: 1,73; IC95\%: 1,11-2,70), eram adotadas (RC: 3,28; IC95\%: 1,52-7,07), terceira ou mais posição entre os irmãos (RC: 2,04; IC95\%: 1,15-3,62), intervalo interpartal anterior (RC: 1,69; IC95\%: 1,13-2,53) ou posterior $<24$ meses (RC: 1,91; IC95\%: 1,16-3,13), gêmeos (RC: 2,40; IC95\%: 1,04-5,50), baixo peso ao nascer (RC: 3,79; IC95\%: 2,38-6,02) e hospitalização no primeiro ano de vida (RC: 1,65; IC95\%: 1,01-2,68). Essas características podem ser utilizadas pelos serviços básicos de saúde na prevenção de retardo no crescimento.

Retardo do Crescimento; Desnutrição; Condições Sociais sent study, maternal schooling was the principal socioeconomic determinant of stunting and low birth weight was the principal individual determinant; the prevalence of 8 years of schooling or less was $48.6 \%$, and the prevalence of low birth weight, $7.9 \%$. Data from the Live Births Information System in Porto Alegre in 200134 showed $44.0 \%$ of maternal schooling less then 8 years and $9.8 \%$ of low birth weight. Although the two studies do not use exactly the same maternal education groups, it is likely that social inequalities and other determinants of stunting are still a public health problem in the city of Porto Alegre, which should be confirmed by further studies.

The determinants of growth retardation identified in this study are in line with the concept of social determination of health 4,5 . Structural factors at the societal level (maternal education and income) were shown to affect children's growth, perhaps due to their influence on environmental variables such as housing quality, mother's age at the child's birth, type of parents, birth order, and birth interval, which are determinants of the child's overall health and growth. Therefore, these determinants of growth can be used by primary healthcare services to identify vulnerable groups in this population, so as to prevent stunting.

\section{Contributors}

D. Aerts contributed with the study design and data collection, analysis, and interpretation. M. L. Drachler participated in the study design and data collection. E. Giugliani collaborated in the data analysis and interpretation. All of the authors participated in drafting the manuscript and revising the final version.

\section{References}

1. Onis M, Frongillo EA, Blossner M. Is malnutrition declining? An analysis of changes in levels of child malnutrition since 1980. Bull World Health Organ 2000; 78:1222-33.

2. Ministério da Saúde. Política nacional de alimentação e nutrição. Brasília: Secretaria de Políticas de Saúde, Instituto Nacional de Alimentação e Nutrição; 2000.

3. Ministério da Saúde. Pesquisa nacional sobre saúde e nutrição: perfil de crescimento da população brasileira de 0 a 25 anos. Brasília: Secretaria de Políticas de Saúde, Instituto Nacional de Alimentação e Nutrição; 1990.

4. United Nations Children's Fund. The state of the world's children, 1998. Oxford: Oxford University Press; 1997. 
5. World Health Organization. Global database on child growth and malnutrition. http://www.who. int/nutgrowthdb/intro_text.htm (accessed on 16/Jun/2003).

6. Monteiro CA. Saúde e nutrição das crianças de São Paulo. São Paulo: Editora Hucitec/Edusp; 1988.

7. Monte CMG. Desnutrição: um desafio secular à nutrição infantil. J Pediatr (Rio J) 2000; 76 Suppl 3:S285-97.

8. World Health Organization. Turning the tide of malnutrition. Document WHO/NHD/00.7. http:// www.who.int/nut/publications.htm\#pem (accessed on 16/Jun/2003).

9. Aerts D. Estudo do estado nutricional das crianças de Porto Alegre: uma contribuição ao entendimento do processo da desnutrição [Master's Thesis]. Porto Alegre: Universidade Federal do Rio Grande do Sul; 1992.

10. World Health Organization. Physical status: the use of anthropometry. Geneva: World Health Organization; 1995.

11. Victora CG, Huttly SRA, Fuchs S, Olinto MT. The role of conceptual frameworks in epidemiological analysis: a hierarchical approach. Int J Epidemiol 1997; 26:224-7.

12. Tabachnik BG, Fidell LS. Review of univariate and bivariate statistics. In: Tabachnik BG, Fidell LS, editors. Using multivariate statistics. San Francisco: Harper \& Row; 1983. p. 24-5.

13. Victora CG, Huttly SRA, Barros FC, Lombardi C, Vaughan JP. Maternal education in relation to early and late health outcomes: findings from a Brazilian cohort study. Soc Sci Med 1992; 34:899-905.

14. Olinto MTA, Victora CG, Barros F, Tomasi E. Determinantes da desnutrição infantil em uma população de baixa renda: um modelo de análise hierarquizado. Cad Saúde Pública 1993; 9 Suppl:14-27.

15. Kikafunda JK, Walker AF, Collet D, Tumwinw JK. Risk factors for early childhood malnutrition in Uganda. Pediatrics 1998; 102:E45.

16. Engstrom EM, Anjos LA. Déficit estatural nas crianças brasileiras: relação com condições sócioambientais e estado nutricional materno. Cad Saúde Pública 1999; 15:559-67.

17. Delpeuch F, Traissac P, Martin-Prevel Y, Massamba JP, Maire B. Economic crisis and malnutrition: socioeconomic determinants of anthropometric status of preschool children and their mothers in an African urban area. Public Health Nutr 2000; 3:39-47.

18. Monteiro CA, Freitas ICM, Baratho RM. Saúde, nutrição e classes sociais: o nexo empírico evidenciado em um grande centro urbano, Brasil. Rev Saúde Pública 1989; 23:422-8.

19. Reichenheim ME, Harpham T. Perfil intracomunitário da deficiência nutricional: estudo de crianças abaixo de 5 anos numa comunidade de baixa renda do Rio de Janeiro (Brasil). Rev Saúde Pública 1990; 24:69-79.

20. Victora CG, Vaughan P, Kirkwood B, Martines JC, Barcelos L. Risk factors for malnutrition in Brazilian children: the role of social and environmental variables. Bull World Health Organ 1986; 64:299309.
21. Leiva L, Burrows R, Macho L, Bravo R, Zvaighaft A, Muzzo S. Etiología del retraso estatural em hijos de adolescentes. Rev Chil Pediatr 1989; 60:88-92.

22. Lima M, Figueira F, Ebrahim GJ. Malnutrition among children of adolescent mothers in a squatter community of Recife, Brazil. J Trop Pediatr 1990; 36:14-9.

23. Cousens SN, Mertens TE, Fernando MA. The anthropometric status of children in Kurunegala district in Sri Lanka: its relation to water supply, sanitation and hygiene practice. Trop Med Parasitol 1990; 41:105-14.

24. Tuncbilek E, Unalan T, Coskun T. Indicators of nutritional status in Turkish preschool children: results of Turkish demographic and health survey. J Trop Pediatr 1996; 42:78-84.

25. Huttly SR, Victora CG, Barros FC, Vaughan JP. Birth spacing and child health in urban Brazilian children. Pediatrics 1992; 89:1049-54.

26. Silva LS, Giugliani ER, Aerts DR. Prevalência e determinantes de anemia em crianças de Porto Alegre, RS, Brasil. Rev Saúde Pública 2001; 35:66-73.

27. Barros FC, Huttly SRA, Victora CG, Kirkwood B, Vaughan JP. Comparison of the causes and consequences of prematurity and intrauterine growth retardation: a longitudinal study in Southern Brazil. Pediatric 1992; 90:238-44.

28. Victora CG, Barros FC, Kirkwood B, Vaughan JP. Pneumonia, diarrhea, and growth in the first $4 \mathrm{y}$ of life: a longitudinal study of 5914 urban Brazilian children. Am J Clin Nutr 1990; 52:391-6.

29. Victora CG, Fuchs S, Flôres JA, Fonseca W, Kirkwood B. Risk factors for pneumonia among children in a Brazilian metropolitan area. Pediatrics 1994; 93:977-85.

30. Kossmann J, Nestel P, Herrera MG, El-Amin A, Fawzi WW. Undernutrition and childhood infections: a prospective study of childhood infections in relation to growth in the Sudan. Acta Paediatr 2000; 89:1122-8.

31. Dibley MJ, Golsby JB, Staehling NW, Trowbridge FL. Development of normalized curves for international growth reference: historical and technical considerations. Am J Clin Nutr 1987; 46:73648.

32. Kuezmarski RJ, Ogden CL, Grummer-Stawn LM, Flegal KM, Guo SS, Wei RL, et al. CDC growth charts: United States. Adv Data 2000; 8:1-27.

33. Garza C, Onis M. A new international growth reference for young children. Am J Clin Nutr 1999; 70 Suppl:169S-72S.

34. Secretaria Municipal de Saúde de Porto Alegre. Dados sobre o Sistema de Informação sobre Nascidos Vivos - SINASC 2001. Porto Alegre: Equipe de Informação/Coordenadoria Geral de Vigilância em Saúde, Secretaria Municipal de Saúde de Porto Alegre; 2002.

Submitted on $31 / \mathrm{Jan} / 2003$

Final version resubmitted on 23/Oct/2003

Approved on 10/Nov/2003 